\title{
Prophecy and Politics in the Old Testament
}

\author{
By BERTIL ALBREKTSON
}

The title of my paper is rather comprehensive and needs some qualification. I shall attempt to discuss some aspects of the subject which may shed light on the theme of this symposium, that is to say aspects which concern the religious legitimation of the state. I shall in the main confine myself to the period of the Israelite monarchy, partly because it is during this particular period-the reigns of David and Solomon, and the time of the divided kingdom down to the exile-that the political organization of Israel may safely be called a state, and partly because the golden age of the prophetic movement falls precisely in this period. I shall first attempt a sketch of the historical and ideological background and then say something about three different groups of prophets: the professional cultic prophets, the early Yahwistic prophets of the type of Elijah and Elisha, and the great prophets.

First a few words about the religious foundation of the state where the prophets acted. That the connection between religion and state, between belief and political existence was intimate in Israel is evident. Before Israel became a state in the more strict sense of the word she existed as a tribal confederacy, and it seems fairly clear that this confederacy was primarily organized for religious, not political purposes. What united the separate tribes was their common worship of Yahweh, the God of Israel. The political unity seems to have grown out of the religious; or, in the words of $G$. Buccellati, "the originating force behind the league was basically cultic and religious". 1 This means that in the case of Israel the state is not the primary fact, not an already existing phenomenon which is given a religious authorization: what we have is a group of human beings which has organized

${ }^{1}$ G. Buccellati, Cities and Nations of Ancient Syria. An Essay on Political Institutions with Special Reference to the Israelite Kingdoms (Studi Semitici, 26), Roma I967, p. II3. 
itself for cultic purposes and which subsequently develops into a political organization, a state.

Buccellati has applied the distinction between territorial states and national states to the political institutions of ancient Syria and Palestine. In territorial states such as Ugarit or Alalakh the feeling of unity, the group solidarity, "was a consequence of common residence in the same territory and of being under a common ruler". ${ }^{1}$ The importance of the territory is further underlined by the fact that it supplies the name for the people living within it. The associative bond in the national states, e.g. Israel or Moab, is of a different character. Here the name is first the name of a group of human beings, a people, and is then transferred to the territory where the people settles down; kinship and tribal solidarity are important social and political factors; the national god contributes vitally to the very identity of the people: Israel is the people of Yahweh as Moab is the people of Chemosh, while corresponding designations do not seem to exist in the case of territorial states. Such features are also characteristic of nomadic groups, and in cases like Israel and Moab they seem to be a heritage from an earlier nomadic or semi-nomadic stage.

It is debatable whether or not Israel was a proper state during the period of the judges - this is, of course, partly a problem of definition. But at all events the establishment of the monarchy was a great and significant change with far-reaching consequences in many spheres. Primarily, of course, it affected the political domain: the very form of Israel's existence as a political unity was radically changed.

At the same time there was a continuity: Israel had been transformed into a monarchy, but the kingdom of Israel was still in a sense the same Israel which had previously been organized as a tribal league. This meant that the new state could inherit the religious legitimation of the old tribal community: as a kingdom, too, Israel was the people of Yahweh. The national identity of the people still had the same religious foundation.

But even if Israel remained the people of Yahweh and could keep the religious traditions which had been the foundation of her earlier existence, the break with the old political organization was nevertheless so radical that

\footnotetext{
${ }^{1}$ Buccellati, p. 63.
} 
the new order needed a special authorization. To be acceptable it had to be associated with the very foundation of the people's existence: the Yahwistic faith itself. And so there developed in Israel a sacral kingship: the ruler in Jerusalem was the son of Yahweh, entrusted with a divine commission. To the covenant of Sinai between Yahweh and his people was added the Davidic covenant between Yahweh and his chosen king. 1 The Sinaitic and Davidic covenants were not incompatible but complementary; from a historical point of view they reflect two stages in the development of Israel: Israel as a tribal confederacy and Israel as a kingdom. The god whom the new king on Zion served and represented was the old tribal god Yahweh, and this combination of continuity and innovation was symbolized by David's ingenious move in bringing the Ark, the most important cult object of the ancient tribal league, to the capital of the new kingdom, the recently conquered Jerusalem. The fusion of old and new was finally manifested in the temple of Solomon: the Ark of the Covenant rested in the Holy of Holies of the royal sanctuary.

Naturally the transition was not without its difficulties. The Old Testament texts testify that opinions were divided. Not all regarded the monarchy as a divine gift; certain traditions in the Books of Samuel, for instance, express a strongly critical attitude towards the new constitution: the people's wish to have a king like all other nations is seen as apostasy from Yahweh, the true King of Israel. "Yahweh said to Samuel, '... they have not rejected you: it is I whom they have rejected from being king over them" " I Sam. 8: 7). But it was not this opinion that prevailed. Characteristic of the victorious view is, rather, the oracle of Nathan to David, the fundamental text for the religious legitimation of the Israelite state: "Thus says Yahweh of hosts, I took you from the pastures, from following the sheep, that you should be prince over my people Israel. ... I will assign a place for my people Israel, and I will plant them, that they may dwell in their own land, and be disturbed no more. ... When your time comes and you rest with your fathers, I will raise up your offspring after you, sprung from your loins, and I will establish his kingdom. ... Your house [i.e., your dynasty]

1 Cf. A. H. J. Gunneweg, "Sinaibund und Davidsbund", Vetus Testamentum, Iо, 1960, p. 335 ff.; Buccellati, p. 2 I I f. 
and your kingdom shall endure for ever before me; ${ }^{1}$ your throne shall be established for ever" (2 Sam. 7: 8, I0, I2, I6).

This, then, is-very briefly-the religious foundation of the state in the Old Testament. But the Old Testament tells not only of sacral kings but also of prophets and men of God who sometimes violently attack Yahweh's Anointed, who criticize and oppose the policy pursued by the representative of God on earth. How do these prophets react to the state and its pretentions to divine establishment?

First we must remember that there were many kinds of prophets in ancient Israel. Great preachers like Isaiah or Jeremiah perhaps come most readily to mind, representatives of the type which we usually call "writing prophets", the "classical" or "great" prophets. But there were also cultic or professional prophets, who were attached to sanctuaries all around the country and to the royal court in Jerusalem, who supplied oracles for a fee and tried in various ways to ascertain the will of Yahweh. A third group consisted of men like Elijah and Elisha, a kind of precursor of the later prophets of doom. To some extent the different groups run into each other, but the division may be defended as a means of marking out certain principal features.

The political part played by the professional and court prophets is fairly unequivocal.2 In Israel like everywhere else in the ancient Near East their task was to pronounce blessings in the state cult and to secure success and prosperity. It was to these prophets that the kings turned on the eve of a campaign or other important enterprises. In the royal cult of the temple of Jerusalem it was probably they who repeated the divine promises of the prophecy of Nathan to new rulers of the Davidic dynasty. The divine oracle to the king in $\mathbb{P s}$. 2, by which his position is guaranteed, is likely to have been uttered by a cultic prophet: "You are my son; today I have begotten you. Ask of me and I will give you the nations as your inheritance and the ends of the earth as your possession. You shall break them with a rod of iron, and shatter them like a clay pot." Thus these prophets-like their colleagues in Babylon or Assyria-supplied in the official cult the religious

\footnotetext{
${ }^{1}$ See the critical apparatus ad loc. in Biblia Hebraica, ed. R. Kittel, Stuttgart I937.

${ }^{2}$ Cf. H.-J. Kraus, Prophetie und Politik (Theologische Existenz heute, N.F. 36), München 1952, p. 4I ff., 49 ff.
} 
legitimation of the state and issued the guarantee for the sovereign. By men like Micah and Jeremiah they were accused of being false prophets: "They say: 'All is well, all is well', though nothing is well' (Jer. 6: 14 ; cf. 23 :I6 ff.).

To describe the political part played by Yahwistic prophets of the type of Elijah and Elisha is considerably more difficult. In their unrelenting criticism of regal abuse of power and state syncretism they anticipate the classical prophets. Especially interesting from our point of view are some cases of prophetic co-operation in revolutions in the northern kingdom, not least because Albrecht Alt has interpreted these cases as evidence of a northern view of the religious legitimation of the monarchy radically different from that current in the kingdom of Judah. ${ }^{1}$ According to Alt, Judah and Israel represent two altogether different ideas about kingship. In the southern kingdom a dynastic principle was in force: an unbroken succession of Davidic descendants ruled in Jerusalem by virtue of Yahweh's eternal covenant with David, a covenant confirmed at each new coronation. In the northern kingdom, on the other hand, there survived a more ancient ideal: a charismatic kingship continued the tradition of the judges, leaders who once stepped forward summoned by Yahweh, without institutional or dynastic legitimation. No dynasty comparable to the Davidic dynasty was ever developed in northern Israel: in contrast to the stability in Judah, there were perpetual rebellions and dynastic changes, and the usurpers authorized the murders of their predecessors with the divine calling through the agency of a prophet. Alt's thesis that this development in the northern kingdom had its roots in an ancient charismatic and anti-dynastic ideal of leadership has been very influential and has coloured the presentation of this period in the leading text-books on the history of Israel: we meet this theory not only in Alt's pupil Martin Noth but also in the American scholar John Bright, who on other points is strongly critical of Alt. Bright in fact goes so far as to speak of "different theories of the state" in the two kingdoms. ${ }^{2}$ If Alt is right, the early prophets of northern Israel may thus be

1 A. Alt, "Das Königtum in den Reichen Israel und Juda", Vetus Testamentum, I, I95I, p. 2 ff., reprinted in Kleine Schriften zur Geschichte des Volkes Israel, 2, München I953, p. II $6 \mathrm{ff}$.

2 J. Bright, $A$ History of Israel, London 1960, p. 216. 
regarded as advocates of a particular ideal of the state, entirely different from that of the Davidic realm.

There is, however, reason to doubt that Alt is right in this question. His arguments and his evidence have been scrutinized in an article by T. C. G. Thornton, "Charismatic Kingship in Israel and Judah", ${ }^{1}$ and at greater length in Buccellati's book Cities and Nations of Ancient Syria. ${ }^{2}$ Both scholars reach the conclusion that Alt's thesis does not bear close examination, and it seems to me that they are in all essentials right. For reasons of space I must confine myself to indicating briefly some of their main points. Alt's use in the first place of the term "charismatic" is debatable. Not only kings in Israel who had been designated by a prophet were regarded as chosen by Yahweh: the kings in Jerusalem were also supposed to have been elected by him and endowed with his special gifts of grace. As a matter of fact it is a common element in the ideology of kingship all over the ancient Near East that the ruler was divinely chosen and empowered to reign. It is perhaps still more striking that there is no direct evidence for Alt's theory: in our sources the alleged charismatic ideology is never invoked in support of the rebellions, and the texts in fact contain no anti-dynastic statements at all. On the contrary there is positive evidence not only that in practice the kingship was sometimes hereditary (this, of course, is admitted by Alt) but also that the dynastic principle was consciously embraced: it can be found precisely in those texts which give the ideological background of the revolts-in fact one of the prophets whom Alt takes as a representative of his alleged charismatic ideal explicitly promises a dynasty to his candidate for the throne. The divine oracle which the prophet Ahijah delivers to Jeroboam, who was to be the first ruler of the northern kingdom, is a perfect parallel to the oracle of Nathan in the south: "... I will be with you, and I will build for you a sure house, as I built for David, and I will give Israel to you" (I Kings II: $3^{8}$ ). That a few prophets in northern Israel preached a theology of revolution and actively supported rebellions is undeniable, but the motive seems primarily to have been religious: they were champions of an old-fashioned Yahwism against the syncretism favoured

\footnotetext{
1 T. C. G. Thornton, "Charismatic Kingship in Israel and Judah", The Fournal of Theological Studies, N.S. I4, r963, p. I ff.

2 Buccellati, p. 200 fr.
} 
by the kings. To regard them as representatives of a special theory of the state is hardly to the point.

Religious motives for political action--this theme leads us to the third and most important group of prophets, those who are commonly called classical. When scholars have discussed prophecy and politics, they have usually had this group in mind.

Looking at the literature about the political activities of the great prophets, one is first struck by the obvious lack of consensus among scholars: the most diverging views have been defended. Paul de Lagarde, the great Septuagint scholar of the Igth century, represented the Israelite prophets as ardent patriots: "in ihnen brennt zum ersten Male in der Geschichte die Flamme der Vaterlandsliebe im reinsten Lichte". ${ }^{1}$ To Hugo Winckler, assyriologist and a leading representative of the pan-Babylonian school, they were instead political agents who ran the errands of foreign powers: Isaiah got his instructions from Niniveh, and Jeremiah acted on orders of Babylon. ${ }^{2}$ Both views - the prophets as whole-hearted patriots or as cunning confidential agents-were of course much too extreme to gain support among the majority of biblical scholars. In particular Winckler's exaggerated emphasis on the political motives behind the activities of the prophets was criticized. As early as $1906 \mathrm{~F}$. Küchler published a treatise which was directly aimed at Winckler's theories; ${ }^{3}$ it discussed Isaiah's attitudes to the politics of his time, and the author's main thesis is that the prophet was in all his dealings determined by ethical and religious motives, not political ones. ${ }^{4}$ This standpoint has been widely accepted in the subsequent discussion, which has been mainly concerned about how this rather general thesis could be more clearly and precisely stated - the bare establishing of religious motives leaves many questions about their kind and character unanswered. Contributions from writers who were not professional biblical scholars have enriched the debate. Ernst Troeltsch, syste-

\footnotetext{
${ }^{1}$ P. de Lagarde, "Die Religion der Zukunft", Deutsche Schriften, I903, p. 224.

2 H. Winckler, "Geschichte und Geographie", in: H. Zimmern and H. Winckler, Die Keilinschriften und das Alte Testament, r903, p. I7 I ff.

${ }^{3}$ F. Küchler, Die Stellung des Propheten Jesaja zur Politik seiner Zeit, Tübingen I906.

${ }^{4}$ Isaiah demanded "dass politische Entscheidungen nicht nach politischen, sondern nach religiösen Gesichtspunkten getroffen werden", Küchler, p. 46 .
} 
matic theologian and philosopher, published in I9I6 a paper on "Das Ethos der hebräischen Propheten" which has been very influential. ${ }^{1} \mathrm{He}$ accepted the view that the political attitudes of the prophets had purely religious grounds, and above all he emphasized the unworldly strain, the prophets' sovereign contempt of the considerations of practical politics: the key word in Troeltsch is utopian. The same strong stress on the utopian element is found in the well-known sociologist Max Weber, who in his great work on Ancient Judaism adopted Troeltsch's view.2 Weber's position is clear even from the following short quotation: "Die politische Stellungnahme der Propheten war rein religiös, durch die Beziehung Jahwes zu Israel motiviert, politisch angesehen aber durchaus utopischen Charakters."'3 For some time this view was quite generally accepted by biblical scholars; it found eloquent expression in the very title of a work by $F$. Weinrich: Der religiös-utopische Charakter der "prophetischen Politik", published in 1932.4

But it did not go unchallenged. In the thirties Karl Elliger protested against the prevalent view of the prophets' utopian attitude to political affairs. ${ }^{5}$ He stated his objections in an inaugural lecture in Leipzig which was published in 1935 and attracted some attention. ${ }^{6}$ Elliger wanted to lay chief stress upon the experiences of the prophets, their conviction that they had received divine revelations. They had been endowed with a special ability to look into the future, they were initiated into the secret plans of Yahweh, they knew what others did not yet know. Elliger therefore preferred to speak of "pneumatischer Realismus" rather than "religiöse

${ }^{1}$ E. Troeltsch, "Das Ethos der hebräischen Propheten", Logos, 6, I9I6, p. I ff., reprinted under the title "Glaube und Ethos der hebräischen Propheten", Gesammelte Schriften, 4, 1925, p. 34 ff.

${ }^{2}$ M. Weber, "Das antike Judentum", Gesammelte Aufsätze zur Religionssoziologie, 3, I 921 , p. I ff.

3 Weber, p. 334 .

4 F. Weinrich, Der religiös-utopische Charakter der "prophetischen Politik" (Aus der Welt der Religion. Biblische Reihe, 7), Giessen I932.

s Cf. also an earlier protest against Weber's view by the Roman Catholic scholar A. Eberharter, Die soziale und politische Wirksamkeit des alttestamentlichen Prophetentums, Salzburg I924, p. $149 \mathrm{ff}$.

'K. Elliger, "Prophet und Politik", Zeitschrift fïr die alttestamentliche Wissenschaft, N.F. 12, 1935, p. $3 \mathrm{ff}$. 
Utopie": 1 precisely because the prophets spoke and acted on the basis of their supernatural insight into future events they were in effect more realistic than the politicians of those times, who lacked this enigmatic gift of knowing the results beforehand.

Elliger may well be right that the prophets' contribution to Israelite politics is too complicated a phenomenon to allow us to reduce it to a simple formula and speak generally of its utopian character. But serious objections can be raised against his reasoning. The most important one seems to me to be that he oversteps the bounds of a scientific treatment of the theme "prophecy and politics" by simply presupposing the existence of supernatural information: "Senkrecht von oben hat ein göttlicher Strahl sie getroffen." 2 That the prophets thought so can, of course, be proved by ordinary empirical methods. But I do not quite see how one could scientifically verify statements like "Isaiah knew that God had decided to act differently from what the politicians thought". ${ }^{3}$ Another objection is that on those points where it is now possible to check the alleged ability of the prophets to predict the future, the result is not particularly promising. Not a few prophetical utterances about future political occurrences can now be controlled after the event, and it appears that about half of these prophecies have not come true. 4 Under such circumstances it seems difficult to speak, as does Elliger, of "ein sicheres Vorwissen". ${ }^{5}$

Hans-Joachim Kraus, in his book on prophecy and politics, ${ }^{6}$ is likewise critical towards the views of Troeltsch and Weber. One of his most important objections is that they operated with an idealistic concept of religion which is not immediately applicable to the Old Testament. He emphasizes that in order to determine correctly the relations between prophecy and politics it is necessary to take the specific historical conditions into account and to

1 Elliger, p. I 5 .

2 Elliger, p. Io.

'Elliger, p. I2: Isaiah "wusste, dass Gott es anders beschlossen hatte, als die Aufständischen mit Ägypten im Rücken es sich dachten”. Cf. also p. 13: Isaiah could proclaim victory during the siege of Jerusalem "weil sein Gott ihm für einen Augenblick die Binde von den Augen nahm, sodass er sah, was andere noch nicht sahen".

${ }^{4} \mathrm{Cf}$. E. Jenni, Die politischen Voraussagen der Propheten (Abhandlungen zur Theologie des Alten und Neuen Testaments, 29), Zürich 1956, p. I I f f.

5 Elliger, p. I I.

${ }^{6}$ See above, p. 48 , note 2 . 
avoid operating with general conceptions. This is no doubt a sound rule of method. How Kraus himself has put it into practice is a different questionhis own inquiry seems to me to be marred by a certain tendency towards simplifications and black-and-white alternatives, and it issues in theses with a strong dogmatic and apologetic tinge which are somewhat difficult to translate into sober scientific prose. However, Kraus is certainly right in stressing the predominance of denunciation and doom in the preaching of the prophets and in emphasizing the importance of this feature for a proper understanding of their political significance. It is remarkable how few concrete political demands they made when they rounded on kings and other leading statesmen with their merciless castigations in the name of Yahweh, how little their indictments were, as a rule, directed towards specific political measures. ${ }^{1}$ The demands were general demands: for justice, faithfulness, mercy. This indicates something essential about the real purposes of the prophets. Joh. Hempel has expressed it very clearly: "nicht das politische Einzelziel ist es, worauf die prophetische Absicht sich richtet, vielmehr geht die Intention auf den religiösen Gehorsam als solchen, in dem Glauben, dass dieser Gehorsam die beste, ja, die einzige wahre Politik sei". ${ }^{2}$ The political accusations are at the same time theological and religious: they are accusations of disobedience and lack of faith: that is what justifies the judgement. ${ }^{3}$ The great prophets do not act as representatives of certain political groups, they do not foment rebellions, they do not conspire against the kings, they do not want to subvert the social order. ${ }^{4}$ But they serve as the conscience of the state. The principles they rely on are no new political programmes or revolutionary doctrines: they remind the kings of the justice of which they are in charge, of their duties according to the covenant with Yahweh, of the demands which are embedded in the religious legitimation on which the kings themselves base their claims. Perhaps the difference

${ }^{1}$ Cf. J. Hempel, Politische Absicht und politische Wirkung im biblischen Schrifttum (Der Alte Orient, 38: r), Leipzig 1939, p. 43.

2 Hempel, p. 43.

' Cf. C. Westermann, "Propheten. Im AT", Biblisch-historisches Handwörterbuch, 3 , r966, col. $\mathrm{r}_{505}$. The prophetic demands are rightly characterized as "Glaubensforderung" by O. Procksch, Der Staatsgedanke in der Prophetie, Gütersloh I933, p. $3 \circ, 33$.

4 Cf. Westermann, col. I 506 . 
between politician and prophet in Israel was sometimes that the rulers treated the time-honoured phrases of the royal ritual as venerable decorations, while to the prophets those ancient words were earnest and deep reality.

This naturally did not prevent individual prophets from displaying considerable political insight and power of judgement. It is difficult to deny that Jeremiah, when he recommended surrender to the Babylonians, had a much clearer grasp of the situation than the activist party at the court which completely controlled the king and his policy. It is also true that the religious convictions of the prophets sometimes compelled them to speak and act in ways which had very definite political implications and effects, ${ }^{1}$ and at times they must have appeared to their antagonists as nothing but plotters and political agitators. Amos is an obvious case (Am. 7: II), and Isaiah's advice to his adherents can be interpreted in a similar direction: "Do not call conspiracy all that this people calls conspiracy" (Is. $8:$ I2). ${ }^{2}$ But this does not alter the main point: the deepest motives underlying the political statements of the prophets were not political but religious, rooted in the holy traditions which formed the religious foundation of the Israelite state.

Was their message also utopian? In spite of the objections raised against Troeltsch and Weber I believe that this label still indicates something essential, even if it cannot be used as an all-embracing formula. It seems incontrovertible that practical considerations of what was politically possible and realistic acquiescence in compromise were entirely foreign to the prophets. Israel should radically abstain from all military alliances and all dependence on human powers and rely solely on the help of Yahwehit is perhaps not unreasonable to call such a defence policy utopian. The prophetic politics is utopian in its very point of departure, its basic presupposition, which has been termed "the prophetic postulate": ${ }^{3}$ the belief that political disasters are a punishment for the apostasy of kings and people, and that the fear of Yahweh is the only way of rescue from defeat and mis-

${ }^{1}$ Cf. F. Wilke, Die politische Wirksamkeit der Propheten Israels, Leipzig 1913, p. 48; Weinrich, p. 27 .

2 On Is. 8: I2 see H. Donner, Israel unter den Völkern. Die Stellung der klassischen Propheten des 8. Fahrhunderts v. Chr. zur Aussenpolitik der Könige von Israel und Fuda (Supplements to Vetus Testamentum, I I), Leiden I964, p. $27 \mathrm{ff}$.

${ }^{3}$ Weinrich, p. 5 . 
fortune-a doctrine of retribution which is actually to some extent indicated in the prophecy of Nathan itself. This attempt to read the vicissitudes of states and sovereigns as a diagram of the effects of the law of retribution was contradicted by the brute facts time and again-most palpably perhaps in the premature death of the pious reformer Josiah at Megiddo. Reality did not conform to the postulate. In their uncompromising assertion of the principles on which the Israelite state cult was ultimately founded the great prophets were indeed utopians. If they had been reasonable and pragmatic we should probably never have heard of them. 